\title{
PENGEMBANGAN KOMIK INTERAKTIF SOAL CERITA MATEMATIKA BERBASIS TPACK UNTUK MENINGKATKAN KETERAMPILAN BERPIKIR KRITIS SISWA KELAS IV SD
}

\author{
Dita Risti \\ Universitas Kristen Satya Wacana \\ 292016118@student.uksw.edu
}

\begin{abstract}
ABSTRAK
Pada pandemi yang sedang dialami, mengakibatkan semua aktivitas menjadi terhambat. Salah satunya adalah pendidikan, dimana proses belajar-mengajar yang dilakukan harus melalui daring. Hal ini guru berperan untuk memunculkan media pembelajaran sebagai sarana untuk belajar siswa secara mandiri dan membantu siswa dalam memahami materi agar tersampaikan secara keseluruhan. Penelitian ini menggunakan metode Research and Development (R\&D). Subjek dalam penelitian adalah siswa kelas IV SD Virgo Maria 2 Bawen, siswa kelas IV SD Randugunting, dan siswa kelas IV SDN Harjosari 01. Pengumpulan data melalui sumber referensi seperti: buku, artikel, dan jurnal yang relevan serta observasi. Teknik analisis digunakan dalam keefetifan, menarik, dan ketepatan sebuah produk yang dikembangkan dengan memperhitungankan persentase rata-rata yang ada dalam instrumen dengan skor item di setiap jawaban pertanyaan dengan jawaban yang tertera pada instrumen. Hasil penelitian menunjukkan, pengembangan produk berupa komik dengan validasi oleh ahli materi mendapat skor $93,62 \%$, ahli media dengan mendapat skor $82,82 \%$, ahli bahasa mendapat skor $87,5 \%$ dan uji coba lapangan kecil oleh beberapa siswa dinilai menarik dan mudah dalam memahami materi serta mampu untuk menyelesaikan soal cerita matematika. Kerangka kerja TPACK dikembangkan pada teknologi yang perpadu dengan pedagogi yang berbentuk media pembelajaran bagi siswa yaitu, komik online yang dapat menarik perhatian dan memudahkan siswa terhadap materi yang dipelajari serta membantu dalam mempengaruhi siswa dalam berpikir kritis.
\end{abstract}

Kata Kunci : Komik Interaktif, Soal Cerita Matematika, TPACK.

\begin{abstract}
In the pandemic that is being experienced, all activities become hampered. One of them is education, where the teaching-learning process that is done must be through online. This teacher plays a role to bring up the medium of learning as a means to learn students independently and help students in understanding the material to be conveyed as a whole. This research uses research and development $(R \& D)$ development methods. The subjects in the study were grade IV student Virgo Maria 2 Bawen, grade IV student Randugunting Elementary, and grade IV student Harjosari 01. Data collection through reference sources such as: relevant books, articles, and journals and observations. Analytical techniques are used in the effectiveness, attractiveness, and accuracy of a product developed by taking into account the average percentage contained in the instrument with the item score in each question answer with the answer listed on the instrument. The results showed that product development in the form of comics with validation by material experts got a score of $93.62 \%$, media experts with a score of $82.82 \%$, linguists got a score of $87.5 \%$ and small field trials by some students were considered interesting and easy to understand the material and able to solve mathematical story problems. The TPACK framework is developed on technology that integrates with pedagogy in the form of learning media for students, namely, online comics that can attract attention and facilitate students to the material studied and help in influencing students in critical thinking.
\end{abstract}

Keywords : Interactive Comics, The Problem of Mathematical Stories, TPACK. 


\section{PENDAHULUAN}

Masyarakat pada abad 21 dituntut untuk lebih kreatif dan inovatif dalam menghadapi berbagai situasi. Pendidikan harus mampu menjamin siswa untuk memiliki keterampilan belajar dan inovasi, keterampilan dalam menggunakan teknologi informasi, dan keterampilan untuk hidup (Wijaya Sudjimat \& Nyoto, 2016). Pada Penelitian ini merajuk pada pengembangan komik interaktif soal cerita matematika untuk meningkatkan keterampilan berpikir kritis siswa kelas IV SD.

Menurut Mediawati (2011, hlm 70) komik secara keseluruhan merupakan kisah yang utuh hasil perkawinan gambar dan tulisan, secara parsial komik merupakan penekanan karakteristik dari segala subyek yang mampu memperkaya setting cerita, baik aspek wujud, gesture, maupun unsur imaji suara. Menurut Yudhi Munadi (2013, hlm 100) komik adalah gambar berkarakter gambar kartun, yang mempunyai sifat yang sederhana dalam penyajiannya dan memiliki unsur urutan cerita yang memuat pesan yang besar tetapi disajikan secara ringkas dan mudah dicerna dilengkapi dengan bahasa verbal yang dialogis untuk mempercepat siswa paham terhadap isi pesan yabentuk ng dimaksud, karena siswa terbantu untuk tetap fokus dan tetap dalam.

Menurut Arsyad (2014) komik adalah cerita yang bertekanan pada gerak dan tindakan yang ditampilkan lewat urutan gambar yang dibuat secara khas dengan paduan kata-kata. Secara umum komik adalah cerita bergambar yang ada gelembung-gelembung atau balon udara. Disimpulkan bahwa komik adalah suatu sarana sumber belajar sebagai alat atau bahan yang berisikan gambar dengan cerita-cerita sederhana yang dilengkapi dengan ilustrasi disajikan secara singkat dan mudah dicerna supaya dapat disukai dan dapat menarik perhatian siswa dan minatnya dalam belajar menyampaikan pesan atau materi pembelajaran. Dalam perancangan komik, diliputi oleh oleh banyak hal yang harus diperhatikan dan diketahui karena komik sendiri merupakan aliran yang berkesinambungan yang terdiri dari pencitraan, alur cerita, dialog, dan gesture.

Menurut Arsyad (2014) ada lima ciri-ciri komik yaitu sebagai berikut: a) bersifat proporsional, membaca komik sanggup membawa pembaca untuk terlibat secara emosional dengan pelaku utama dalam cerita komik tersebut; b) humor yang kasar, penggunaan bahasa lisan dan mudah dimengerti oleh setiap yang membaca; c) bahasa percakapan, menggunakan bahasa percakapan sehari-hari akan lebih mengena bagi setiap yang membaca; d) penyederhanaan perilaku yang menggambarkan moral atau jika pelaku dalam cerita komik 
cenderung untuk disederhanakan dan mudah diterka; e) bersifat kepahlawanan, isi komik cenderung membawa pembaca untuk memuja pahlawannya.

Ada dua macam komik berdasarkan jenis ceritanya dan berdasarkan bentuknya. Berdasarkan jenis cerita komik terbagi menjadi empat macam, sebagai berikut: (a) Komik Promosi (komik iklan): komik biasanya muncul dengan banyak ragam dan dapat menumbuhkan dan menciptakan imajinasi seseorang yang selaras dengan dunia anak, komik juga dipakai untuk sebuah produk. Komik promosi ini biasanya digunakan untuk figur superhero atau tokoh yang merupakan manifestasi citra dari produk yang dipromosikan. (b) Komik Silat: tema-tema silat dalam komik yang didominasi oleh adegan pertarungan yang sampai saat ini masih menjadi idola. Dengan mengatur setting cerita, komi ini menyesuaikan budaya masing-masing sesuai dengan negara yang menerbitkannya. Misalnya saja China dengan bela diri kungfunya. (c) Komik Wayang: komik ini mengisahkan tentang cerita wayang. Misalnya cerita Ramayana tentang penculikan Dewi Sinta oleh Rahwana. Komik ini muncul tahun 6070-an dengan komik yang popular seperti Lahirnya Gatotkaca, Pangeran Palasara, dan Mahabharata karya R.A Kosasih yang terkenal, terbitan Melodi dari Bandung. (d) Komik Edukasi: keragaman cerita dan gambar pada komik menjadikannya sebagai media atau alat untuk menyampaikan pesan yang beragam. Komik ini memberikan kontribusi cukup besar dalam intelektual dan artistik seni. Salah satunya pesan kepada masyarakat. Dengan demikian, komik memiliki dua fungsi. Pertama berfungsi sebagai hiburan, yang kedua dapat dimanfaatkan untuk langsung dan tidak langsung untuk tujuan edukatif. Dikarenakan komik yang makin berkemang kearah yang lebih baik dengan adanya kesadaran masyarakat akan nilai edukatif yang biasa dibawanya.

Berdasarkan bentuknya komik terbagi menjadi lima, yaitu sebagai berikut; (a) Komik strip (Comic Strips): komik ini terdiri dari beberapa panel saja dan muncul di surat kabar atau majalah. Contohnya: komik strip bersambung. (b) Buku komik (Comic Book): komik ini dibuat dalam bentuk buku yang bukan bagian dari media cetak lainnya. Cover dari komik ini biasanya lebih menyerupai majalah dan terbitnya secara rutin. (c) Novel Grafis (Graphic Novel): merupakan tema yang dimiliki lebih serius dengan panjang cerita yang hampir sama dengan novel dan ditujukan kepada pembaca dan bukan untuk anak-anak. (d) Komik Kompilasi: komik ini merupakan kumpulan dari beberapa judul komik dan komikus yang berbeda-beda. (e) Web Comic (Komik Online): komik ini digunakan media internet untuk publikasi dan jangkauan yang sangat luas dan tak terbatas. 
Menurut Munadi (2010) media e-komik merupakan media bergambar menyerupai kartun, yang berbentuk sederhana dan memiliki alur cerita serta pesan pada setiap dialog tetapi disajikan secara ringkas dan mudah dipahami. Menurut Arsyad (2014) ada empat hal yang berpegang dalam pengembangan e-komik yaitu, sebagai berikut; (a) Bentuk: pemilihan bentuk ilustrasi yang diperhatikan untuk membangkitkan minat dan perhatian siswa. (b) Garis: digunakan untuk menghubungkan unsur yang bersifat berurutan, agar unsur garis ini membantu dalam kejelasan cerita. (c) Tekstur: tekstur berfungsi menimbulkan kesan halus atau kasar yang menunjukkan unsur penekanan. (d) Warna: berfungsi untuk memberikan kesan pemisah atau penekanan serta membangun keterpaduan dan mempertinggi realitas objek dan menciptakan respon emosional.

Menurut Susiani (Arsyad (2014) ada enam bagian dalam e-komik yaitu, sebagai berikut: (a) Karakter, tokoh dalam komik. (b)Frame, batas adegan cerita satu dengan yang lain. (c) Balon kata, percakapan yang diucapkan oleh karakter. (d) Narasi, kalimat penjelas yang dikemukakan komikus. (e) Efek suara, efek yang diberikan pada visualisasi pada kalimat yang diucapkan oleh karakternya.

Menurut Umam dkk (2014) mengungkapkan bahwa soal cerita matematika adalah soal berupa kalimat cerita dengan menggunakan bahasa sehari-hari yang diubah menjadi kalimat matematika atau persamaan matematika. Sedangkan menurut Wahyuddin (2016) soal cerita dikatakan sebagai bentuk evaluasi siswa yang telah mendapatkan suatu pelajaran. Berdasarkan dari uraian yang telah dijabarkan pengertian tentang soal cerita matematika yang adalah kalimat-kalimat cerita dengan memakai bahasa sehari-hari yang diubah menjadi persamaan matematika dan menjadi sebuah evaluasi siswa ketika telah mendapatkan suatu pembelajaran.

Berdasarkan data PISA tahun 2009 dalam Ariyadi Wijaya (2012: 1-2) menyatakan bahwa diperoleh hasil hampir setengah siswa Indonesia (43, 5\%) tidak mampu menyelesaikan soal PISA paling sederhana. Sekitar sepertiga siswa Indonesia yaitu (33, 1\%) hanya bisa mengerjakan soal dari kontekstual yang diberikan secara eksplisit serta data yang dibutuhkan untuk mengerjakan soal diberikan secara tepat. Hanya 0, 1\% siswa Indonesia mampu mengerjakan dan mengembangkan pemodelan matematika yang menuntut keterampilan berpikir dan penalaran.

Menurut Turmudi (Abdul, 2015, hlm. 3-4) menyatakan bahwa bertahun-tahun telah diupayakan agar matematika dapat dikuasai siswa dengan baik oleh ahli pendidikan dan ahli 
pendidikan matematika, tetapi masih menunjukkan bahwa tidak banyak siswa yang tidak menyukai matematika, dikarenakan oleh anggapan bahwa matematika itu merupakan mat pelajaran yang rumit". Namun, matematika bukan hanya berbentuk angka saja tetapi juga dalam bentuk soal cerita. Soal cerita matematika adalah soal berupa kalimat cerita yang menggunakan bahasa sehari-hari, kemudian diubah menjadi kalimat matematika atau persamaan matematika. Maka dari itu, komik menjadi salah satu pilihan yang menunjang pembelajaran soal cerita matematika, karena bukan hanya berbentuk cerita bergambar yang berwarna, tetapi bahasa yang digunakan mudah untuk siswa pahami dan kalimat yang digunakan tidak panjang lebar (Wahyuddin, 2016, hlm. 112).

Menurut Polya (Zulfianti, 2016, hlm. 36-37) menjelaskan secara rinci langkahlangkah empat tahap pemecahan masalah matematika yaitu sebagai berikut: (a) Memahami masalah: Polya mengungkapkan bahwa tahap ini memberikan bimbingan kepada siswa untuk mengetahui apa yang diketahui dan apa yang ditanyakan menurut soal yang diberikan. Jika siswa mengalami kesulitan, maka pengajar memberikan bimbingan atau arahan dengan mengubah soal dengan kalimat sendiri. Dengan itu, siswa melatih diri untuk belajar menulis apa yang telah diketahui dan apa yang ditanyakan. (b) Merencanakan pemecahan: tahap ini dilakukan saat mencari hubungan data yang telah diketahui dan dengan data yang belum diketahui. Hal ini dilakukan jika siswa mengerjakan langkah pertama yaitu memahami masalah dengan benar. (c) Melaksanakan rencana pemecahan: bila sudah memahami masalah dengan baik dan sudah menentukan langkah-langkah atau strategi pemecahannya, yang selanjutnya adalah melaksanakan rencana. Jika langkah menyelesaikan masalah telah dilakukan, maka selanjutnya harus dicek jawaban atau hasil yang diperoleh sudah benar atau belum. Memeriksa setiap langkah yang telah dibuat dan harus dilihat dengan teliti bahwa langkah tersebut sudah benar. (d) Memeriksa kembali pemecahan: kegiatan yang dilakukan pada langkah terakhir adalah memeriksa kembali hasil yang telah diperoleh dengan soal aslinya. Setelah hasil dari penyelesaian diperoleh, perlu dicek kembali dan memastikan jawaban yang diperoleh sudah benar dan tepat.

Soal cerita matematika yang dikemas dengan cara yang berbeda akan memberikan dampak yang baik agar siswa mempunyai rasa ingin tahu tentang materinya. Dikarenakan matematika yang berbentuk cerita, maka dengan menggunakan media yang mampu merubah pemikiran siswa tentang matematika. Salah satu yang dapat digunakan adalah dengan komik. Komik adalah gambar berkarakter dengan penyajian yang sederhana dan urutan cerita yang 
memuat pesan secara ringkas dan mudah dicerna serta diperlengkapi dengan bahasa yang mudah dipahami oleh siswa agar dapat memahami pesan yang dimaksud (Yudhi Munadi, 2013, hlm. 100).

Pendidikan di Indonesia yang berkembang melalui teknologi, mengakibatkan perubahan yang signifikan bagi perkembangan proses pembelajaran yang mengharuskan pengajar memiliki kompetensi mengenai teknologi dan mempunyai kemampuan memanfaatkan teknologi ke dalam pembelajaran. Meningkatkan mutu pembelajaran dengan teknologi dapat dilakukan, salah satunya dengan menggunakan kerangka kerja TPACK (Technological, Pedagogical, and Content Knowledge). Menurut Koehler \& Mishra (Yundayani, 2019, hlm. 2) mengungkapkan bahwa TPACK menggunakan pengetahuan tentang materi pembelajaran, pedagogi, yang merupakan kerangka kerja yang menggunakan teknologi dalam proses pembelajaran. Dikarenakan saat ini pembelajaran dilakukan secara daring atau online. Permasalahan yang dialami adalah tidak semua pelajaran dapat siswa tangkap saat pembelajaran online. Maka dari itu diperlukan media pembelajaran secara online yang dapat menunjang belajar siswa. Salah satu yang menjadi kendala adalah pelajaran matematika.

Menurut Ennis dalam Susanto (2013, hlm. 125) terdapat indikator kemampuan berpikir kritis yaitu a) memberikan penjelasan sederhana; b) membangun kemampuan dasar; c) menyimpulkan; d) memberikan penjelasan lebih lanjut; e) mengatur strategi dan taktik. Keterampilan berpikir kritis tidak terjadi dengan sendirinya, namun dapat berkembang dengan sendirinya seiring dengan perkembangan fisik manusia. Keterampilan ini yang harus dilatih dengan pemberian stimulus dengan menuntut seseorang untuk berpikir kritis. Proses berpikir kritis diperoleh melalui pembelajaran dari berbagai disiplin ilmu yang salah satunya ditekankan dalam pembelajaran.

Menurut Widyastuti \& Pujiastuti (2014, hlm. 184) menyatakan bahwa kemampuan berpikir logis adalah kemampuan siswa dalam berpikir untuk menarik kesimpulan yang sah menurut logika. Jadi, kemampuan berpikir kritis atau logis ini bukan merupakan hasil transfer ilmu dari seseorang ke orang lain dalam hal ini guru ke siswa, tetapi dibentuk sendiri oleh siswa melalui pengalaman nyata dengan mengaitkan pengetahuan yang telah dimilikinya. Menurut Lau (2011, hlm. 1) berpikir kritis adalah berpikir jernih dan rasional. Melibatkan berpikir tepat dan sistematis, dan mengikuti aturan logika dan penalaran ilmiah. Berpikir kritis melibatkan kelengkapan penggunaan standar, seperti kejelasan, akurasi, 
relevansi, dan). Dapat disimpulkan pengertian keterampilan berpikir kritis adalah berpikir rasional yang harus dilatih secara terus-menerus dengan pengalaman nyata yang alami oleh seseorang dan mampu untuk menyelesaikannya.

Menurut Facione (dalam Peter, 2012) menyatakan bahwa siswa yang berpikir kritis menggunakan langkah-langkah tersebut untuk memecahkan masalah: (a) Identify (I): Ide pokok dari permasalahan yang dihadapi. (b) Define (D): Menentukan permasalahan yang diketahui dan soal yang ditanyakan. (c) Enumerate (E): Menentukan pilihan jawaban akhir yang diambil sebagai pilihan yang benar. (d) Analyze (A): Menganalisis pilihan dari jawaban yang benar. (e)

List (L): Memilih suatu jawaban yang tepat untuk dipilih. (f) Self-Correct (S): Mengecek kembali secara cermat dan menyeluruh untuk menghindari menyelesaian soal yang mungkin terlewatkan.

Pembelajaran yang diterapkan dengan menggunakan kerangka kerja TPACK, maka dapat digunakan teknologi untuk mengembangkan sebuah komik online yang dapat membantu siswa dalam belajar. Menurut Pamudji (2014, hlm. 3) mengungkapkan bahwa ecomic adalah multimedia dengan penyajian menggunakan teknologi agar menjadi lebih menarik dalam penggunaannya, sehingga siswa dapat menggunakan gadget maupun proyektor. Untuk membantu siswa dalam belajar dapat dibentuk komik yang interaktif yang artinya komik memberikan ruang untuk siswa seperti berinteraksi dengan komik yang siswa baca. Isi dari komik online yang diberikan adalah siswa bukan hanya sekedar membaca saja tetapi dari setiap halaman siswa akan diberi pertanyaan dan jawaban. Hal ini diupayakan agar siswa memiliki rasa ingin tahu saat membaca dan mencoba untuk menjawab dengan kritis agar dapat mengetahui hasil dari jawaban siswa, agar dapat membaca komik di halaman selanjutnya.

Tujuan dari pengembangan komik interaktif soal cerita matematika yang berbasis TPACK untuk meningkatkan keterampilan berpikir kritis siswa kelas IV SD adalah untuk memudahkan pengajar dalam mengajar materi matematika yang berbentuk soal cerita. Dimana banyak siswa yang kurang mengerti jika berbentuk cerita, maka dengan itu digunakan sebuah komik yang banyak siswa suka karena bentuk komik yang menarik, berwarna, bertokoh, bahasa yang digunakan sederhana dan kalimat yang tidak panjang. Maka dengan itu, kembangkan melalui teknologi yaitu sebuah komik online yang interaktif 
untuk dapat menunjang belajar siswa. Dengan bentuk online dapat membantu siswa dalam pembelajaran secara daring atau online.

\section{METODE PENELITIAN}

Penelitian ini menggunakan metode penelitian dan pengembangan Research and Development (R\&D). Menurut Sugiyono (2015, hlm. 407) Research and Development (R\&D) merupakan metode penelitian yang digunakan untuk menghasilkan produk tertentu dan menguji keefektifan produk tersebut. Model pengembangan ini terdiri dari 10 langkah, yaitu: 1) potensi dan masalah; 2) pengumpulan data; 3) desain produk; 4) validasi desain; 5) revisi desain; 6) uji coba produk; 7) revisi produk; 8) uji coba pemakaian; 9) revisi produk; 10) produk masal. Tetapi peneliti hanya penelitian pada tahap ke-tujuh yaitu revisi produk dikarenakan karena ada kendala finansial dan waktu yang ada.

Tahap pengembangan meliputi validasi produk oleh tim ahli diikuti dengan revisi dan uji coba produk pada kelompok kecilTim ahli yang melakukan validasi produk dalam penelitian ini adalah Dani Kusuma, M.Pd. dan Yohana Setiawan, S.Pd., M.Pd. Sedangkan yang menjadi subyek penelitian adalah siswa kelas IV SD Virgo Maria 2 Bawen, siswa kelas IV SD Randugunting, dan siswa kelas IV SDN Harjosari 01. Instrumen yang digunakan dalam penelitian ini adalah validasi oleh ahli bahasa dan media yaitu, dosen Dani Kusuma, M.Pd. serta ahli materi yaitu, dosen Yohana Setiawan, S.Pd., M.Pd.

Teknik pengumpulan data yang dilakukukan dengan observasi dengan mengamati kondisi dan situasi yang pada kegiatan belajar matematika pada materi FPB yang sedang dipelajari oleh siswa. Pengamatan yang berlangsung dapat disimpulkan bahwa siswa kesulitan untuk mengikuti pelajaran matematika dengan materi soal cerita. Selain karena harus membaca terlebih dahulu juga harus mencermati soal untuk menjabarkan jawaban dengan model matematika. Dikarena soal cerita matematika berbentuk kalimat cerita, maka diperlukan media pembelajaran untuk menunjang materi agar dapat dikuasai oleh siswa. Salah satunya dengan penggunaan komik, selain karena kalimat yang digunakan sederhana dan tidak panjang tetapi juga menarik untuk siswa. Observasi yang telah dilakukan siswa banyak yang menyukai dan sangat berminat untuk membaca komik.

Teknik analisis data adalah analisis data dengan mendeskripsikan lembar penelitian dengan mengedepankan saran, tanggapan, dan pemikiran dari validator. Analisis data yang dilakukan melihat dari nilai aspek instrumen. Teknik analisis yang digunakan dalam keefetifan, menarik, dan ketepatan sebuah produk yang dikembangkan dengan 
memperhitungankan persentase rata-rata yang ada dalam instrumen dengan skor item di setiap jawaban pertanyaan dengan jawaban yang tertera pada instrumen. Langkah-langkah analisis data adalah sebagai berikut:

Tabel 1 Pedoman Skor Penilaian

\begin{tabular}{lc}
\hline \multicolumn{1}{c}{ Data Kualitatif } & Skor \\
\hline Sangat Baik (SB) & 5 \\
Baik (B) & 4 \\
Cukup ( C ) & 3 \\
Kurang (K) & 2 \\
Sangat Kurang (SK) & 1 \\
\hline *Sumber: Usman dan Akbar (2011)
\end{tabular}

Dari Perhitungan tersebut ditentukan persentase yang telah diolah dengan rumus:

$$
P S=\frac{S}{N} \times 100 \%
$$

Keterangan:

Ps : Persentase

S : Jumlah jawaban responden dalam satu item

N : Jumlah nilai ideal dalam item (Riduwan, 2014, hlm. 39)

Selanjutnya untuk menghitung nilai skor rata-rata persentase angket dengan menggunakan rumus sebagai berikut:

$$
P=\frac{\Sigma P}{N}
$$

Keterangan:

$\mathrm{P} \quad$ : Rata-rata presentase

$\sum \mathrm{P}$ : Jumlah keseluruhan presentase

$\mathrm{N}$ : Jumlah keseluruhan item pada angket

Setelah persentase nilai telah ditemukan, maka selanjutnya menentukan tingkat pencapaian yang telah ditentukan pada sebuah tabel, sebagai berikut:

Tabel 2 Tingkat Pencapaian

\begin{tabular}{ll}
\hline $\begin{array}{c}\text { Tingkat } \\
\text { Pencapaian }\end{array}$ & \multicolumn{1}{c}{ Keterangan } \\
\hline $81-100 \%$ & Sangat layak, tidak perlu direvisi \\
$61-80 \%$ & Layak, tidak perlu revisi \\
$41-60 \%$ & Kurang layak, perlu revisi \\
$21-40 \%$ & Tidak layak, perlu revisi \\
$<20 \%$ & Sangat tidak layak, perlu revisi \\
\hline
\end{tabular}


Berdasarkan rumus perhitungan yang dijabarkan tersebut, media pembelajaran dapat dikatakan layak, jika persentase lebih dari $61 \%$.

\section{HASIL DAN PEMBAHASAN}

Berdasarkan dari kerangka kerja TPACK yang mengarah pada teknologi dan berpacu dengan pedagogi serta materi yang telah dirancangkan, maka peneliti merancang pembuatan komik interaktif online dengan merancang karakter tokoh yang akan ditampilkan. Selanjutnya dengan membuat dan mengisi panel-panel komik dengan gambar serta balon dialog yang disesuaikan dengan pembahasan materi yang akan dikembangkan oleh penulis. Pada setiap halaman komik interaktif dibentuk ke beberapa bagian yang diisi dengan gambar karakter atau tokoh komik interaktif dan juga balon dialog percakapan. Ada beberapa contoh dari komik yang telah dikembangkan dengan berisikan materi matematika.

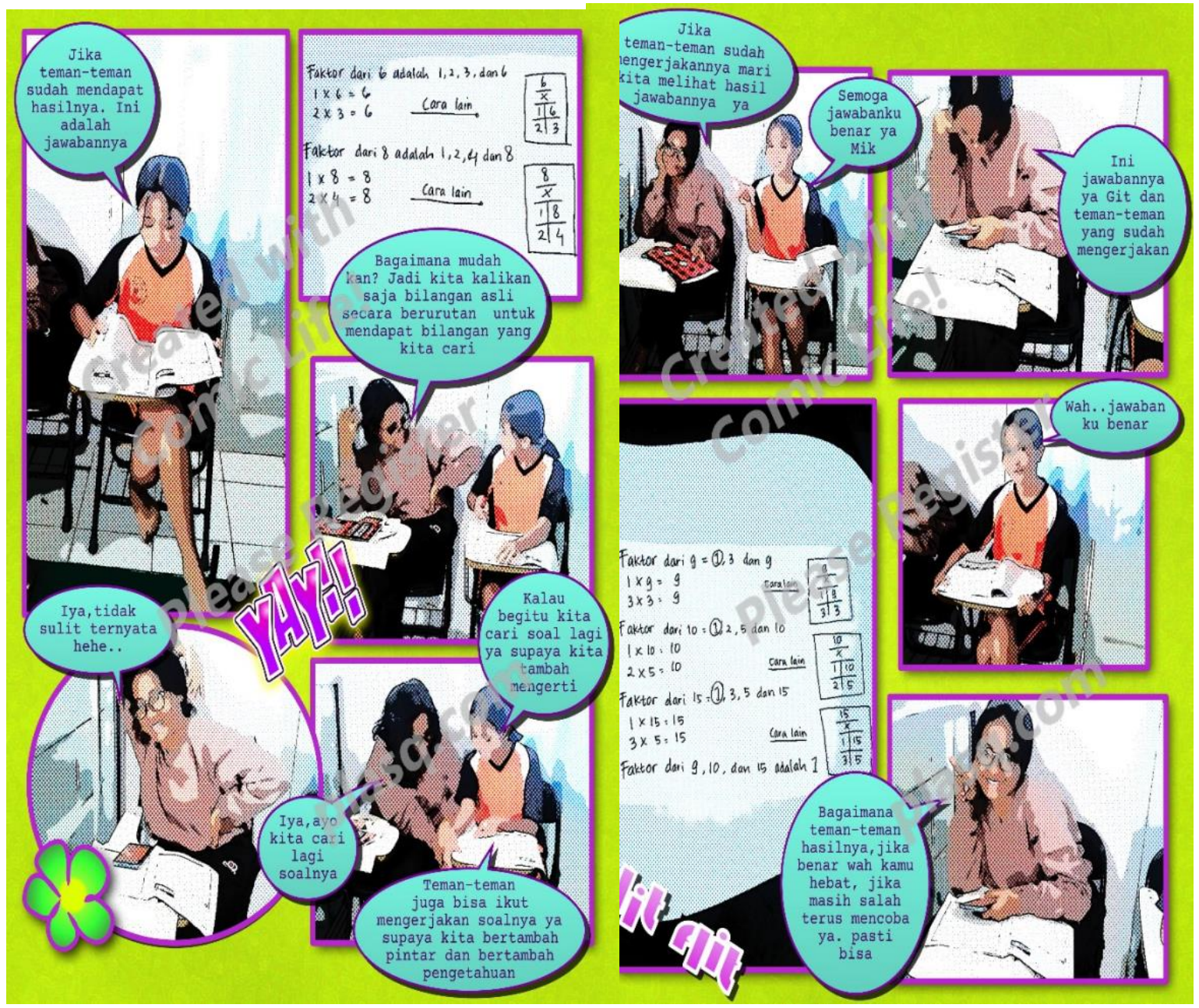

Gambar 1. Pengembangan komik interaktif 
Komik tersebut dibuat dengan menggunakan aplikasi comic life 3. Karakter yang telah dirancang dari hasil foto yang dikumpulkan sesuai dengan alur cerita yang akan dibuat. Hasil foto tersebut diatur dengan menggunakan filter dan memilih retro (atau sesuai dengan kebutuhan yang akan digunakan untuk membentuk efek yang diinginkan). Kemudian dapat membuat balon kata sesuai yang isinya disesuaikan dengan materi matematika dan diletakkan sesuai dengan urutan cerita.

Komik interaktif yang telah dikembangkan sebagai media belajar siswa, akan dapat membantu siswa dalam kesulitan memahami materi matematika yang berbentuk kalimat yang panjang. Karena dengan observasi yang telah dilakukan dan dengan melihat bukubuku yang banyak dibaca oleh siswa dan yang sebagian besar siswa sukai yaitu komik, dengan demikian akan dapat membantu untuk proses belajar dengan menggunakan komik sebagai media pembelajaran.

Pada kegiatan proses belajar-mengajar yang dilakukan secara daring, membuat siswa harus belajar secara mandiri dan pengajar hanya akan memberikan materi secara online dan pengajarannya juga terbatas. Maka dari itu, dengan adanya komik interaktif sebagai media pembelajaran dapat dibuat secara online, yang dapat dikirimkan oleh setiap siswa. Komik online tersebut dapat berupa JPG ataupun PDF.

Komik interaktif yang dibuat untuk media pembelajaran materi matematika adalah soal cerita matematika. Dikarenakan bentuk dari soal cerita matematika yaitu kalimat cerita yang pajang dan harus mencermati agar dapat dengan mudah untuk menjabarkan ke dalam model matematika. Dengan media pembelajaran yaitu komik interaktif akan membantu siswa, karena selain dalam bentuk komik disertai dengan karakter dan bahasa yang digunakan sederhana akan dapat dengan mudah siswa fokus dalam membaca karena tertarik dan menyenangkan.

Soal cerita matematika dalam bentuk komik interaktif secara online sebagai media pembelajaran untuk siswa, dapat meningkatkan keterampilan berpikir kritis. Karena dengan belajar mandiri yang berpusat pada siswa, akan melatih siswa untuk berpikir secara kritis, selain karena keingintahuan siswa terhadap komik yang interaktif. Siswa akan dilatih untuk mencoba dan menyelesaikan masalah.

Hasil dari penelitian ini menyajikan data yang diperoleh dari proses pengembangan dan pembuatan produk, hasil validasi oleh ahli materi, ahli bahasa, ahli media dan uji coba lapangan kecil. 


\section{Potensi dan masalah}

Proses belajar yang dilakukan siswa tidak lagi berpacu dengan buku pelajaran dan paket. Dengan teknologi yang berkembang, siswa dapat dengan mudah belajar dari manapun. Teknologi yang digunakan dalam proses pembelajaran sudah banyak yang diaplikasikan seperti google meet, google classroom, google, YouTube dan masih banyak yang lainnya. Bahkan dalam pembelajaran daring atau secara online, siswa dan guru menggunakan aplikasi tersebut untuk tetap dapat melakukan pembelajaran. Meski tidak bertatap muka secara langsung, tetapi teknologi mempermudah dalam belajar.

Pembelajaran yang diterapkan dengan menggunakan kerangka kerja TPACK juga mengacu pada pedagogi yang artinya strategi pengajaran yang akan dipelajari oleh siswa di kelas, seperti model atau metode untuk menyajikan mata pelajaran. Salah satunya dengan penggunaan media pembelajaran. Dengan teknologi dapat mempermudah dalam penggunaan media pembelajaran. Media pembelajaran adalah penunjang untuk materi dimengerti oleh siswa.

Salah satu pembelajaran yang di pelajari oleh siswa adalah matematika. Di mana matematika bukan hanya dalam bentuk angka tetpai juga cerita, seperti soal cerita matematika. Tetapi, dari observasi yang sudah dilakukan siswa belum memahami dengan benar tentang materi soal cerita matematika. Perlu adanya inovasi baru untuk menyampaikan materi soal cerita matematika yang menarik agar siswa mau untuk belajar, ada keinginan siswa untuk mencoba dan berpikir kritis untuk menyelesaikan soal cerita dengan caranya. Tentunya ada banyak cara untuk dapat mengatasinya. Salah satunya dengan menggunakan media pembelajaran yaitu komik. Komik sangat menarik untuk dijadikan sebagai media pembelajaran karena tidak terlalu banyak teks, mempunyai karakter, dan warna yang menarik. Bentuk komik yang digunakan dalam pembelajaran dalam menunjang teknologi adalah komik online atau e-comic. Dengan menggunakan teknologi yang mengembangkan komik online yang berisakan materi soal cerita matematika untuk meningkatkan keterampilan berpikir kritis siswa. Agar siswa menjadi semangat dalam belajar dan rasa ingin tahu yang tinggi supaya menumbuhkan siswa dalam berpikir kritis.

\section{Validasi desain}

Validasi desain merupakan proses untuk menilai suatu rancangan produk yang akan dibuat, dengan melalui pengembangan komik interaktif soal cerita matematika berbasis TPACK untuk meningkatkan keterampilan berpikir kritis siswa kelas IV SD. Siswa akan 
lebih tertarik dan lebih fokus serta kreatif dalam menjalankan aktivitas pembelajaran maka dilaksanakan validasi desain, di mana validasi yang akan dilakukan berkaitan dengan media pembelajaran yang akan dibuat yaitu komik interaktif.

\section{Data hasil validasi ahli materi}

Penilaian ini dilakukan dengan cara memberikan produk yang dikembangkan yaitu, komik dan juga instrumen lembar penilaian yang akan diisi oleh dosen ahli materi. Penilaian dari ahli materi yaitu meliputi aspek pembelajaran dan materi. Validasi ahli materi dilakukan dengan tujuan agar mendapatkan produk yang sesuai dengan kebutuhan siswa.

Tabel 1. Data hasil validasi penilaian ahli materi

\begin{tabular}{lrrrl}
\hline $\begin{array}{c}\text { Aspek } \\
\text { Penilaian }\end{array}$ & \multicolumn{1}{c}{$\begin{array}{c}\text { Jumlah Per } \\
\text { Aspek }\end{array}$} & $\begin{array}{c}\text { Skor } \\
\text { Maksimal }\end{array}$ & Skor \% & Kategori \\
\hline Pembelajaran & 23 & 25 & $92 \%$ & Sangat Layak \\
Materi & 30 & 35 & $85,71 \%$ & Sangat Layak \\
\hline Jumlah total & & & & 53 \\
\hline Skor maksimal & & & 60 \\
\hline Presentase & & & & $93,62 \%$ \\
\hline Kriteria & & & Sangat Layak \\
\hline
\end{tabular}

Berdasarkan data dari hasil validasi materi pada aspek pembelajaran memperoleh jumlah per aspek 23 dengan skor maksimal 25 serta persentase 92\%, aspek materi memperoleh jumlah 30 dengan skor maksimal 35 serta persentase 85,71\%. Berdasarkan persentase skor yang diperoleh rata-rata skor 93, 62\% dengan kriteria sangat layak dari jumlah total 53 dengan skor maksimal 60. Hal tersebut diperkuat dengan adanya pernyataan dari ahli materi bahwa komik interaktif ini telah layak tanpa direvisi kembali.

Data hasil validasi ahli media

Penilaian ini dilakukan dengan cara memberikan komik interaktif dan instrument lembar penilaian yang akan diisi oleh dosen ahli media. Penilaian yang akan diberikan oleh ahli media adalah aspek pewarnaan, tampilan pada layar dan penyajian.

Tabel 2. Hasil validasi ahli media

\begin{tabular}{lccrl}
\hline Aspek Penilaian & $\begin{array}{c}\text { Jumlah per } \\
\text { Aspek }\end{array}$ & $\begin{array}{c}\text { Skor } \\
\text { Maksimal }\end{array}$ & $\begin{array}{c}\text { Skor } \\
(\boldsymbol{\%})\end{array}$ & Kategori \\
\hline Pewarnaan & 8 & 10 & $80 \%$ & Layak \\
Tampilan pada layar & 35 & 40 & $87,5 \%$ & Sangat Layak \\
Penyajian & 5 & 5 & $100 \%$ & Sangat Layak \\
\hline Jumlah total & & & & 48 \\
\hline Skor maksimal & & & 55 \\
\hline Presentase & & & $81,82 \%$ \\
\hline Kriteria & & & Sangat Layak \\
\hline
\end{tabular}


Berdasarkan data dari hasil validasi media dapat dilihat aspek penilaian pewarnaan memperoleh jumlah per aspek 8 dengan skor maksimal 10 serta persentase $80 \%$, aspek penilaian tampilan pada layar memperoleh jumlah 35 dengan skor maksimal 40 serta persentase $87,5 \%$, aspek penilaian penyajian memperoleh jumlah 5 dengan skor maksimal 5 serta persentase $100 \%$. Berdasarkan persentase skor rata-rata $81,82 \%$ dengan kriteria sangat layak dari jumlah total 48 dengan skor maksimal 55. Hal tersebut diperkuat dengan dari ahli media bahwa komik interaktif telah layak dan sudah direvisi.

\section{Data hasil validasi ahli bahasa}

Penilaian dilakukan dengan memberi komik interaktif dan instrumen lembar penilaian yang akan diisi oleh ahli bahasa. Penilaian oleh ahli bahasa meliputi aspek kesesuaian bahasa.

Tabel 3. Hasil validasi ahli bahasa

\begin{tabular}{lcccl}
\hline Aspek Penilaian & $\begin{array}{c}\text { Jumlah per } \\
\text { Aspek }\end{array}$ & $\begin{array}{c}\text { Skor } \\
\text { Maksimal }\end{array}$ & Skor\% & Kategori \\
\hline Kesesuaian bahasa & 35 & 40 & $87,5 \%$ & Sangat Layak \\
\hline Jumlah Total & & & 35 \\
\hline Skor Maksimal & & 40 \\
\hline Presentase & & $87,5 \%$ \\
\hline Kriteria & & Sangat Layak \\
\hline
\end{tabular}

Berdasarkan data hasil penilaian ahli bahasa di atas pada aspek kesesuaian bahasa memperoleh jumlah 35 dengan skor maksimal 40 serta persentase 87,5\% dengan kriteria sangat layak. Hal tersebut diperkuat dengan adanya pernyataan dari ahli bahasa bahwa komik interaktif telah layak.

Revisi desain, pada tahap ini, setelah selesai dengan desain produk yang telah divalidasi oleh ahli materi, media dan bahasa maka dapat diketahui kekurangan yang ada pada komik. Setelah merevisi desain, produk yang akan diperbaiki agar dapat menciptakan produk yang lebih baik. Tujuan dari tahap revisi desain adalah untuk dapat memperbaiki kelemahan produk yang didapat setelah dilakukannya uji validasi oleh para validator pada tahap sebelumnya. Revisi pada komik dilakukan pada saat bimbingan dengan dosen ahli untuk menemukan kekurangan pada komik. Setelah tidak ada revisi pada bimbingan maka diadakanlah penilaian tanpa revisi.

Uji coba produk, setelah dilakukannya validasi desain dan juga melakukan revisi desain maka tahap selanjutnya adalah masuk kepada tahap uji coba. Uji coba produk sangatlah penting dalam proses penelitian. Uji lapangan terhadap komik interaktif ini 
dilakukan pada siswa kelas IV SD. Peneliti mengumpulan beberapa siswa kelas IV SD dari sekolah yang berbeda-beda. Uji coba lapangan ini dilakukan melalui satu tahap saja, yaitu uji coba kelompok kecil (uji coba terbatas). Uji coba kelompok kecil dilakukan dengan cara mengambil beberapa siswa. peneliti mengambil sampel dari beberapa siswa yang berbeda sekolah, diantaranya adalah kelas IV SD Virgo Maria 2 Bawen, kelas IV SD Randugunting, dan kelas IV SDN Harjosari 01. Uji coba kelompok kecil ini dilakukan pada hari Selasa, 9 November 2021. Responden diminta untuk membaca komik interaktif dengan dikumpulkan di satu ruangan dan mengerjakan melalui handphone. Siswa belajar soal cerita matematika secara mandiri. Berdasarkan dari hasil yang telah dilihat, bahwa siswa sangat tertarik dengan komik interaktif yang telah dibaca dan siswa tersebut mengerti dalam mengerjakan soal cerita matematika yang diberikan oleh siswa melalui komik interaktif.

Revisi produk, dilakukan pada saat berkonsultasi dengan ahli materi, ahli bahasa, ahli media sebelum dilakukannya penilaian validasi pada instrumen yang diberikan. Berdasarkan dari hasil validasi produk yang telah dilakukan tidak mengalami hambatan sampai produk dinyatakan telah layak. Hasil dari uji coba produk saat di lapangan sedikit mengalami hambatan, yaitu peneliti sulit mendapat persetujuan dari orang tua murid untuk mengadakan pertemuan secara online melalui web meet. Hambatan yang diberikan adalah tidak memiliki finansial untuk membeli paket data untuk siswa. Hambatan juga dirasakan oleh guru yang mengajar yaitu dengan hambatan dari orang tua siswa yang tidak memiliki finansial untuk membeli kebutuhan paket data untuk siswa dengan pembelajaran yang dilakukan secara online. Maka dari itu pembelajaran dilakukan melalui Whatsapp dan diberikan print out materi dan soal untuk siswa dengan datang di hari yang ditentukan oleh guru kelas.

\section{KESIMPULAN}

Berdasarkan penelitian yang telah dilaksanakan, diperoleh kesimpulan, bahwa pada pandemi yang sedang dialami, mengakibatkan semua aktivitas menjadi terhambat. Di mana proses belajar-mengajar yang dilakukan harus melalui daring. Hal ini guru berperan untuk memunculkan media pembelajaran sebagai sarana untuk belajar siswa secara mandiri dan membantu siswa dalam memahami materi agar tersampaikan secara keseluruhan. Salah satunya dengan menggunakan kerangka kerja TPACK dikembangkan pada teknologi yang perpadu dengan pedagogi yang berbentuk media pembelajaran bagi siswa yaitu, komik online yang dapat menarik perhatian dan memudahkan siswa terhadap materi yang dipelajari serta membantu dalam mempengaruhi siswa dalam berpikir kritis. Karena dengan belajar 
yang terpusat pada siswa, akan melatih siswa untuk berpikir secara kritis, selain karena keingintahuan siswa terhadap komik yang interaktif. Siswa akan dilatih untuk mencoba dan menyelesaikan masalah.

\section{UCAPAN TERIMA KASIH}

Berdasarkan penelitian yang telah dilakukan peneliti mengucapkan terima kasih kepada dosen pembimbing Krima Widi Wardani, S.Pd., M.Pd. yang telah banyak membantu dalam penelitian dan kepada rekan-rekan yang telah membantu dalam pengolahan data.

\section{REFERENSI}

Abdullah, A. H. (2015). Analysis of Student' Errors in Solving Higher Order Thinking Skills (HOTS) Problem for the Topic of Fraction". Asian Social Science,11(21), 134-142.

Akbar, P. U. (2011). Metodologi Penelitian Sosial. Jakarta: Bumi Aksara.

Arikunto. (2010). Prosedur Penelitian Suatu Pendekatan Praktik. Jakarta: Graha Ilmu.

Arsyad, A. (2014). Media Pembelajaran. Jakarta: Rajawali Pers.

Ihsan, M. \&. (2016). Analisis Kemampuan Menyelesaikan Soal Cerita Matematika Ditinjau dari Kemampuan Verbal pada Siswa VII SMP Muhammadiyah Se-Kota Makasar. Suska Journal of Mathematics Education (p-ISSN: 2477-4758|E-ISSN: 2540-9670) Vol.2 No. 2, 111-116.

Lau, J. (2011). An Introduction to Critical Thinking and Creativity. New Jersey: Wiley.

Meidiawati, E. (2011). Pembelajaran Akuntansi Keuangan Melalui Media Komik untuk Meningkatkan Prestasi Mahasiswa. Jurnal Penelitian Pendidikan Vol. 12, No. 1.

Munadi, Y. (2010). Media Pembelajaran. Jakarta : Gaung Persada (GP) press.

Munadi, Y. (2013). Media Pembelajaran (Sebuah Pendekatan Baru). Jakarta : Referensi.

Pamuji, M. B. (2014). Pengembangan Komik Sebagai Media Pembelajaran Biologi Pada Materi Sistem Saraf Manusia untuk SMP/Mts Kelas IX Semester Ganjil. Yogyakarta: Fakultas Sains dan teknologi Universitas Islam Negeri Sunan Kalijaga.

Peter, E. (2012). Critical Thinking: Essence for Teaching Mathematics and Mathematics Problem Solving Skills. Journal of African Journal of Mathematics and Computer Science Research. Vol.5, No.3, 39-43.

Riduwan. (2014). Dasar-Dasa Statistika. Bandung: Alfabet.

Sugiyono. (2015). Metode Penelitian Kombinasi (Mix Methods). Bandung: Alfabeta.

Susanto, A. (2013). Teori Belajar dan Pembelajaran di Sekolah Dasar. Jakarta: PT Kharisma Putra Utama.

Umam, M. D. (2014). Analisis Kesalahan Siswa dalam Menyelesaikan Soal Cerita Matematika Materi Operasi Hitun Pecahan. Jurnal Ilmiah Pendidikan Matematika Volume, 3(3). 
Widyastuti, N. \&. (2014). Pengaruh Pendidikan Matematika Realistik Indonesia (PMRI) Terhadap pemahaman Konsep dan Berpikir Logis Siswa. Jurnal Prima Edukasia, 183193.

Wijaya, A. (2012). Pendidikan Matematika Realistik: Suatu Alternatif Pendekatan Pembelajaran Matematika . Yogyakarta: Graha Ilmu.

Wijaya, E. Y. (2016). Transformasi Pendidikan Abad 21 Sebagai Tuntutan Pengembangan Sumber Daya Manusia di Era Global. Prosiding Seminar Nasional Pendidikan Matematika, 1, pp: 263-278.

Yundayani, A. (2019). Technological Pedagogical and Content Knowledge : Konsep Analisis dalam Pengembangan Pembelajaran. STKIP Kusuma Negara.

Zulfianti. (2016). Pengaruh Tipe Pembelajaran Kooperatif dan Gaya Belajar Terhadap Kemampuan Pemecahan Masalah Siswa Kelas X SMA Wahyu Makassar (Studi pada Materi Reaksi Oksidadi dan Reduksi). Makassar. 